Health, 2021, 13, 1-1

\title{
In Mourning and Memory of Late Professor Kuo-Chen Chou (1)
}

\section{Leonid P Titov}

Corresponding Member of the National Academy of Sciences of Belarus, Belarus

Email: leotit310@gmail.com

Professor Kuo-Chen Chou, founder and honorary editor of the Health magazine died on the 5th of July at the Brigham Women Hospital of lung cancer, aged 82. From the moment the journal was founded until the very last days, he paid great attention to developing a strategy for the development of the journal as an international one, creating a platform for doctors, researchers in the field of medicine and academic workers to put forward new ideas, methods, and discuss prospects. He was a world-famous scientist and leader in the field of biophysics and bioinformatics, the most frequently cited author of scientific papers. He made a great contribution to the development of these scientific areas. World science has lost a great scientist and a man. I first met Professor Kuo-Chen Chou in 2012 in Shanghai during an international scientific conference on bioinformatics, which was well organized and held at a high scientific level. Throughout all the years of our fruitful cooperation, I have met with understanding and support. We deeply mourn the loss of Professor Kuo-Chen Chou, and we dedicate this note to him. We express our condolences to the family and friends. The memory of him will remain in our hearts.

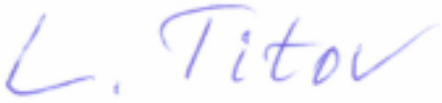

Prof. Leonid P Titov

Editor-in-Chief of journal HEALTH

How to cite this paper: Titov, L. P, (2021) In Mourning and Memory of Late Professor Kuo-Chen Chou (1). Health, 13, 1-1. https://dx.doi.org/10.4236/health.2021.137A001

Received: July 12, 2021; Published: July 16, 2021

Copyright (C) 2021 by author(s) andScientificResearch Publishing Inc.This work is licensed under the CreativeCommons Attribution International License (CC BY 4.0). http://creativecommons.org/licenses/by/4.0/ 